\title{
Polymorphism Identification of Pit1 Gene in Indonesian Buffaloes (Bubalus bubalis) and Holstein-Friesian Cows
}

\author{
R. Misrianti ${ }^{*}$, C. Sumantri ${ }^{a}$, \& A. Farajallah ${ }^{\mathrm{b}}$ \\ aDepartment of Animal Production and Technology, Faculty of Animal Science, Bogor Agricultural University \\ Jln. Agatis, Kampus IPB Darmaga Bogor 16680, Indonesia \\ bepartment of Biology, Faculty of Mathematic and Natural Science, Bogor Agricultural University \\ Darmaga Campus, Bogor 16680 \\ (Received 30-03-2010; accepted 29-12-2010)
}

\begin{abstract}
Pit-1 gene has been identified as the pituitary specific transcription factor that regulates the expression of the growth hormone (GH) and prolactin (PRL) genes in the anterior pituitary. The use of polymorphic markers in breeding programmes could make selection more accurate and efficient. A total of 320 Indonesian buffaloes from four populations and $45 \mathrm{FH}$ cows from nine populations were genotyped for polymorphism of Pit1|Hinf1 gene by the polymerase chain reaction and restriction fragment length polymorphism (PCR-RFLP) methods. The gene polymorphism was detected only in FH cattle. The frequency of $\mathrm{AA}, \mathrm{AB}$, and $\mathrm{BB}$ genotype was $2 \%, 44 \%$, and $53 \%$ respectively. The frequency of A allel was $25 \%$ and $B$ allel was $75 \%$, but no polymorphism was detected in 320 Indonesia buffaloes.
\end{abstract}

Key words: buffalo, Pit1 gene, PCR RFLP

\section{INTRODUCTION}

Indonesian buffaloes (Bubalus bubalis) is one of the important large ruminants to be improved due to its desirable characters to adapt to low quality vegetation and to survive against tropical parasites. A various number of essential functions of buffalo coming from a commonly traditional production system are basically for sources of meat, millq draft power, manure, social and culture attributes giving a significant contribution to the national livestock production.

In an effort to maintain, explore and develop the potential genetic of Indonesian buffaloes, identification of the performance and genetic parameters is needed, primarily related to important economic trait. Origin of information (gene flow), the characteristics of livestock (production traits and reproduction) and characteristics of population (diversity, the status of the population) of local buffalo yet well known. Though the information is important for the development and improvement of genetic quality of local buffalo as part of the development of national buffalo, information genetics of Indonesian buffaloes is very low. This might partly be due to the lower performance of buffaloes with respect to economic important traits when compared to cattle, limiting the interests in buffalo genome analysis in the developed

\footnotetext{
* Corresponding author:

e-mail: rest 42@yahoo.co.id
}

countries (Kierstein et al., 2004). However, the domestic buffalo holds a great economic potential in the developing countries. Buffalo is admired as multipurpose animal for dairy, meat, and drought. The stock of domestic water buffalo is estimated to be around 130 million, which is around $1 / 9$ of the total worldwide cattle population (FAO \& IINEP, 2000).

Growth and carcass traits, which are under the control of multiple genes, are economically important traits in livestock. Selection of animals with higher growth rate and better carcass composition is of great significance to breeders and consumers. Current technologies likely enable animal breeder to improve on the accuracy and efficiency of traditional selection methods by applying genetic markers through marker-assisted selection. Pituitary-specific transcription factor responsible for pituitary development and hormone expression in mammals. Pit1, which is also termed growth hormone factor I (GHFI), is a pituitary-specific transcription factor that is responsible for pituitary development and hormone expression in mammals. Pit1 is a member of the POU domain containing proteins, which is a group of transcriptional regulators that have a critical role in differentiation and proliferation of cells (Zhao, 2002). The inhibition of Pit1 synthesis has been associated with marked decrease of both GH and PRL expression and proliferation of somatotropic and lactotropic cell lines (Castrillo et al., 1991).

Bovine Pit1 is a 129 amino acid protein and member of DNA-binding POU family of homeo domain 
transcription factor. This has been sublocalized to the centromeric region of bovine chromosome 1, located midway between TGLA57 and RM95 (Moody et al., 1995). The RFLP within bovine Pit1 gene with respect to Hinf I restriction enzyme (Pit1/Hinf I) was first identified by Woollard et al. (1994). Several workers since then have investigated its association with growth, body weights, carcass traits, lactating performance (Renaville et al., 1997).

Pit1 polymorphism already reported in bovine, sheep, pig and goat. Moody et al. (1995) identified in bovines the A and B alleles of the Pit1 gene polymorphism, which is an exon 6, A to G silent mutation of the bovine Pit1 gene (Curi et al., 2006) which probably is not direct responsible for phenotypic variation, although relationships have been observed between POUIFl polymorphisms and body weight and somatic measures (Renaville et al., 1997; Dybus et al., 2004), weaning and yearling weight.

In goat, Pit1 gene locates in chromosomes lq2l-22 and is separated into six exons containing a POU domain and homeodomain (Woollard et al., 2000). Lan et al. (2007) identified silent allele at goat Pit1 gene and association with production traits. The result showed Pitl gene had a positive effect on milk performance and early weight trait. In 2009, Lan et al. (2009) identified twelve novel SNPs of the goat Pit1 gene and their associations with cashmere traits.

Sumantri et al. (2009) identified polymorphism of Pituitary specific transcription factor I (Pit1) gene in Indonesian local sheep. These result indicated Pit1 genotype had no significant effect on dam body weight and milk production. Yu et al. (1995), reported association of Pit1 polymorphisms with growth and carcass traits in pigs. These results suggest that Pit1 or a closely linked gene to Pit1 may be important in birth weight and carcass fat traits in swine.

Previous studied observed in Iranian river buffalo, indicated low variation of these genes in buffalo (Javanmard et al., 2005). Renaville et al. (1997) showed that there is a high variation of Pit1 gene in $\mathrm{FH}$ cows and the A allele (especially the AB genotype) may have an effect on milk yield and its components. Therefore, the information genetic variation in pituitary specific transcription factors I (Pit1) gene is necessary observe in Indonesian buffaloes and Indonesian Friesian Holstein cows. Therefore, the purpose of this study was to analyze the genetic variability of the Pitl gene in population of the Indonesian buffaloes and $\mathrm{FH}$ cows by using PCR-RFLP.

\section{MATERIALS AND METHODS}

\section{Sample and Bleeding Location}

A total of 365 (buffaloes $(n=320)$ and Friesian Holsteins $(n=45))$ were used in this study. Whole blood buffaloes were collected from four populations: Central Java $(n=75)$, West Nusa Tenggara $(n=103)$, North Sumatra $(n=65)$, and Banten $(n=77)$. In order to compare the polymorphism of pituitary specific transcription factor I (Pit1) gene in Indonesian buffaloes, with 45 blood samples of FH cows from 9 populations: Ngantang $(n=5)$, Boyolali $(n=5)$, Livestock Embryo Transfer Center $(n=5)$, Koperasi Persusuan Bandung Utara (KPSBU) $(n=5)$, Institute for Animal Research and Technology $(n=5)$, Bali $(n=5)$, Kunak $(n=5)$, Singosari $(n=5)$, and Pasir Kemis $(n=5)$ were analyzed. Blood samples were collected from the jugular vein using vacuum tubes containing with heparin. Blood samples were stored in absolute alcohol.

\section{DNA-Extraction}

The genomic DNA was isolated using proteinase $\mathrm{K}$ digestion followed by Sambrook et al. (1989). Blood samples were washed with destilated water and centrifuged at $8000 \mathrm{rpm}$ for $5 \mathrm{~min}$. The supernatant was discarded. In order to digest protein in the suspension, 400 $\mu \mathrm{l}$ lysis buffer containing proteinase K $10 \mu \mathrm{l}$, SDS $40 \mu \mathrm{l}$, and 1xSTE $350 \mu \mathrm{l}$ and the samples were incubated at 55 ${ }^{\circ} \mathrm{C}$ for two hour. An equal volume of phenol-chloroform $(1: 1 \mathrm{v} / \mathrm{v})$ was added and the two phases were mixed until emulsion was formed. The two phases were separated by centrifugation at $12000 \mathrm{rpm}$ for $5 \mathrm{~min}$. The aqueous supernatant solution was collected in fresh sterilized tubes. Phenol-chloroform extraction was repeated. The DNA was washed with $70 \%$ ethanol and dried. Finally the DNA was dissolved with elution buffer.

\section{PCR Condition}

The sequences of the forward and reverse primer for amplification of the Pit1 gene was designed based on Javanmard et al. (2005) No acc Y15995 and AM490263 (Table 1). The polymerase chain reaction for the Pit1 gene was performed in a $25 \mu$ l reaction mixture, containing 1 $\mu \mathrm{l} \mathrm{MgCl}_{2}, 0.5 \mu \mathrm{l}$ of each dNTPS, $1 \mu \mathrm{l}$ of each primer, $10 \mathrm{x}$ buffer, I U taq polymerase, $2 \mu$ genomic DNA template and $17.9 \mu \mathrm{l}$ destilated water. The reaction mixture was placed in a PCR machine with conditions included: an initial denaturation step at $95{ }^{\circ} \mathrm{C}$ for $2 \mathrm{~min}$ followed by 30 cycles of $95^{\circ} \mathrm{C}$ for $45 \mathrm{sec}, 60^{\circ} \mathrm{C}$ for $1 \mathrm{~min}$, and $72{ }^{\circ} \mathrm{C}$ for $1 \mathrm{~min}$ and final extension at $72{ }^{\circ} \mathrm{C}$ for $3 \mathrm{~min}$.

Table 1. Forward and reverse primers for the amplification of the Pit-1gene

\begin{tabular}{cccc}
\hline Primer pair name & Primer sequence & Product size & Amplified region \\
\hline Pit1 F & 5'-GAGCCTACATGAGACAAGCATC-3' & 611bp & Exon 6 \\
Pit1 R & 5'-AAATGTACAATGTGCCTTCTGA-3' & & \\
\hline
\end{tabular}




\section{Genotyping by PCR-RFLP (Polymerase Chain Reaction-Restriction Fragment Length Polymorphism)}

Five $\mu \mathrm{l}$ PCR product of Pit1 gene were digested with restriction enzyme Hinfl at $37{ }^{\circ} \mathrm{C}$ for at least 14 h. The digested fragments separated by $12 \%(\mathrm{w} / \mathrm{N})$ polyacrilamid gel using a 100 base pair (bp) molecular weight standard to calculate the size of the amplified and digested fragments were visualized by silver staining and exposed to ultraviolet light. The genotypes of the individual cattle were determined for each polymorphism by analyzing the size of the fragments reported as base pairs.

\section{Statistical Analysis}

The allele and genotype frequencies were estimated by direct counting according to Nei procedure (Nei \& Kumar, 2000).

$$
\chi_{\mathrm{i}}=\left(2 \mathrm{n}_{\mathrm{ii}}+\sum_{\mathrm{j} \neq \mathrm{i}} \mathrm{n}_{\mathrm{ij}}\right) /(2 \mathrm{~N})
$$

Where:

Xi : gene frequency of Pit1 genotype-i

nii : number of sample with Pit1 genotype ii

nij : number of sample with Pit1 genotype ij

$\mathrm{N}$ : total sample population

\section{RESULTS AND DISCUSSION}

Pit1 gene fragment was successfully amplified using PCR (polymerase chain reaction) technique for all samples. The amplification of the Pit1 gene fragment resulted in a single product of $611 \mathrm{bp}$ (Figure 1). Annealing temperature used for amplification of this fragment was $60{ }^{\circ} \mathrm{C}$. This temperature was same with annealing temperature being used by Javanmard et al. (2005).
Polymorphic of exon 6 Pit1 gene was already described by Javanmard et al. (2005) in Iranian buffalo. Sequence analysis of Hinf1 site in the Pit1 gene revealed a mutation at position 1256 that was a G to A (Figure 2). In cattle, polymorphic in intron 5 and exon 6 in Nanyang cattle was described by Xue et al. (2006).

\section{Genetic Polymorphism of the Pit1 Gene in Indonesian Buffaloes}

PCR-RFLP (restriction fragment length polymorphism) using Hinf1 restriction enzyme was used to genotype the Indonesian buffaloes. In homozygous animals either a unique band (611 bp, AA variants) or two bands (367 and $244 \mathrm{bp}, \mathrm{BB}$ variant). Heterozygous animal gave a three band $(611,367$, and $244 \mathrm{bp})$. No polymorphism was detected in exon 6 Pit1|Hinf1 in four populations of Indonesian buffaloes (Banten, North Sumatera, Central Java, Nusa Tenggara Barat (NTB)). Results on Pit1 polymorphisms by Hinf1 enzyme show just one alleles (B) and all of the genotypes is BB (Figure 3).

In Iranian buffalo (Javanmard et al., 2005), the amplification of the Pit1 gene fragment resulted in a

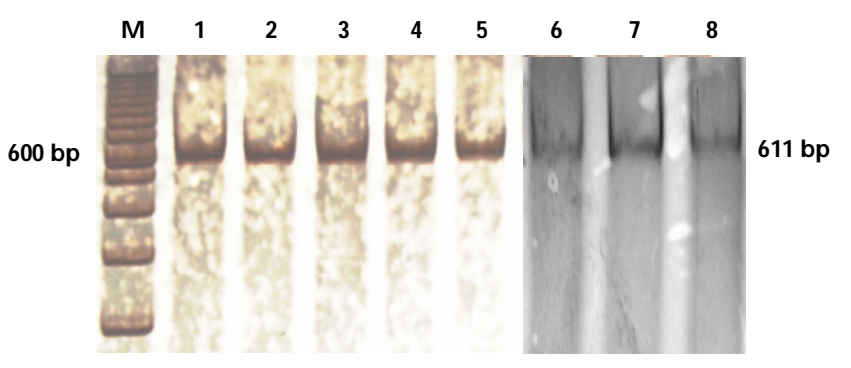

Figure 1. Polymerase chain reaction (PCR) product of Pit1 gene. M: marker; 1-5: PCR products of the Pit1 gene in buffalo; 6-8 PCR product of Pit1 gene in FH cattle.

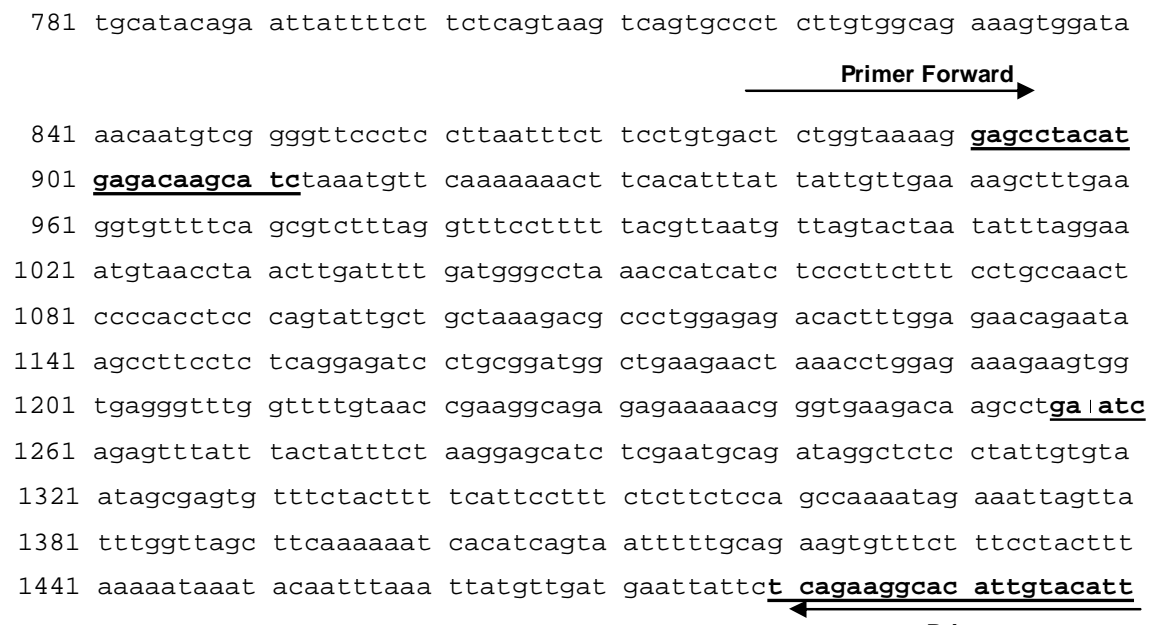

Figure 2. The pattern corresponding to the sequence Pit1 gene in cattle (Gene Bank accession Y15995 dan AM490263). Restriction site mutation at position 1256 ( $\mathrm{G}$ to $\mathrm{A}$ ). 


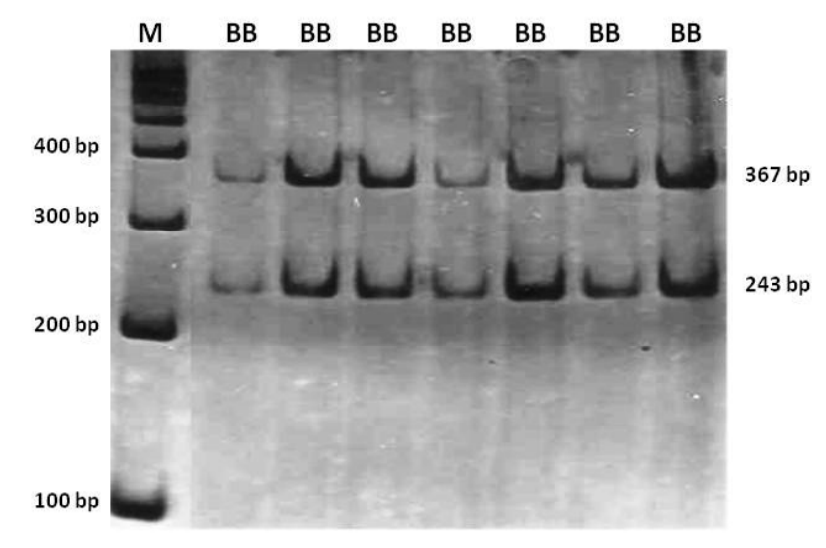

Figure 3. Polymerase chain reaction-restriction fragment length polymorphism (PCR-RFLP) electrophoretic pattern of exon 6 of Pit1 gene of the Indonesian local buffalo in PAGE $12 \%$ showing genotype BB.

single product of $600 \mathrm{bp}$. In homozygous animal either a unique band (600 bp, AA variants) or two bands (357 bp and $243 \mathrm{bp}, \mathrm{BB}$ variant). Heterozygous animal gave three band $(600,357$ and 243 band).

\section{Genetic Polymorphism of the Pit1 Gene in Indonesian Friesian Holstein Cows}

Blood samples from nine populations in Indonesian FH cows were successfully indentified by using PCRRFLP method. Hinf1 restriction enzyme was used to genotype the Indonesian $\mathrm{FH}$ cows. Restriction pattern of Pit1 Hinf1 gene have three genotypes of $A A, A B$, and $\mathrm{BB}$ upon digestion of the Pit1 HinfI. AA variants showed single band ( $611 \mathrm{bp}), \mathrm{BB}$ variants showed two band (357 and $243 \mathrm{bp}$ ), and $A B$ variants showed three bands (611 bp, $367 \mathrm{bp}$, and $243 \mathrm{bp}$ ) (Figure 4).

Similar findings were obtained by many workers who detect the fragments after digestion (Woollard, 1994; Zwierzchowski, 2002; Javanmard et al., 2005). Pit1 polymorphism in bovine and buffalo was detected by Zhao et al. (2004) used SSCP method. In human, Pit1

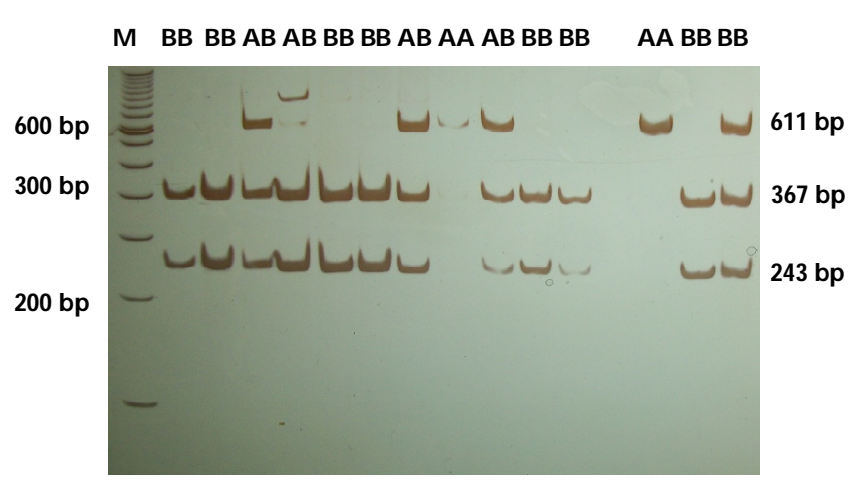

Figure 4. Polymerase chain reaction-restriction fragment length polymorphism (PCR-RFLP) electrophoretic pattern of exon 6 of Pit1 gene of the Indonesian FH cattle in PAGE $12 \%$. polymorphism was detected by Kishimoto et al. (2002). Sequence analysis of the polymorphic HinfI site revealed a mutation at position 1256 . The mutation was a $G$ to $A$ transition (Figure 5).

\section{Alel A : : 5'---- GACAAGCCTAAATCAGAGTTTAT----- 3' Alel B : 5 ---- GACAAGCCTGAATCAGAGTTTAT----- 3'}

Figure 5. Sequence analysis of the polymorphic HinfI site revealed a mutation at position 1256 . The mutation was a $G$ to A transition.

\section{Genotype and Gene Frequencies of Pit1|Hinf1 in Indonesian Buffaloes}

Table 2 showed there is no variation genotype in Indonesian buffaloes. Considering the 320 buffalo analyzed, the overall genotype frequencies was BB (100\%). The Pit1 B allele frequency was observed to be the highest $(100 \%)$ in the studied population (Table 1). This result was different to that reported gene frequencies of Pit1 variant in Iranian buffalo (Javanmard et al., 2005). In Iranian buffalo genotype frequencies were 0.567 for AA, 0.4 for $A B$, and 0.3 For $B B$. In which, gene frequencies for A allel was 0.766 and B allel was 0.3578 .

In Iranian buffalo, gene frequency of A allele was higher than that of B allele. But in Indonesia, gene frequency of B allele was higher than A allele. Different result might be caused by different species of buffalo. Javanmard et al. (2005) identified polymorphism of Pit1 IHinf1 in river buffalo, but in this research, identified polymorphism of Pit1 IHinf1 in swamp buffalo.

Renaville et al. (1997) reported the association of A allele at Pit1 |Hinf1 locus with superior milk and protein yields and inferior for fat percentage in dairy cattle. Similarly Zwierzchowski et al. (2002) showed that the allele A of the Pit1 locus had positive effect on milk production traits. In beef cattle, Zhao et al. (2004) reported that Pit1 IHinf1 polymorphism appears to effect growth traits in Angus cattle and may be a candidate gene for Marked Assisted Selection (MAS).

\section{Genotype and Gene Frequencies of Pit1|Hinf1 in Indonesian $\mathrm{FH}$ cows}

Genotype frequencies of 45 Friesian-Holstein cows were 0.02 for $\mathrm{AA}, 0.44$ for $\mathrm{AB}$, and 0.53 for $\mathrm{BB}$. Gene frequencies of $\mathrm{A}$ allele and $\mathrm{B}$ were 0.25 and 0.75 respectively (Table 4). This results were higher than those the frequencies obtained by Zwierzchowski et al. (2001) for different breeds of Bos Taurus, Angus (0.55), Holstein (0.74), Brahman (0.75), Polish (0.75) and Gry cattle (0.05) but lower than Hereford (0.79), and Glbvieh (0.9) breed (Zwierzchowski et al., 2002).

This fact is almost the same with the previous observations of Renaville et al. (1993). The AA pattern was less frequent than the $\mathrm{AB}$ or $\mathrm{BB}$ patterns. The significant superiority of the Pit1 A allele over the B allele was observed for milk yield, protein yield, body depth, angularity, and rearleg set (Jawasreh et al., 2009).

Lan et al. (2007) identified the silent allele at the goat Pit1 locus. Genomic DNA samples were obtained from 
Tabel 2. Genotype and gene frequencies of the Pit | Hinf1 in the Indonesian buffaloes

\begin{tabular}{lcccccc}
\hline \multirow{2}{*}{ Population } & $\mathrm{N}$ & \multicolumn{3}{c}{ Genotype frequencies } & \multicolumn{2}{c}{ Alelle frequencies } \\
\cline { 3 - 7 } & & AA & AB & BB & A & B \\
\hline NTB & 103 & 0 & 0 & $103(1.00)$ & 0 & 1 \\
Central Java & 75 & 0 & 0 & $75(1.00)$ & 0 & 1 \\
North Sumatera & 65 & 0 & 0 & $65(1.00)$ & 0 & 1 \\
Sum & 243 & 0 & 0 & $243(1.00)$ & 0 & 1 \\
\hline
\end{tabular}

Table 3. Genotype and gene frequencies of the Pit|Hinf1 in the Friesian-Holstein cows

\begin{tabular}{lcccccc}
\hline \multirow{2}{*}{ Location } & $\mathrm{N}$ & \multicolumn{3}{c}{ Genotipe frequencies } & \multicolumn{2}{c}{ Alelle frequencies } \\
\cline { 3 - 7 } & & $\mathrm{AA}$ & $\mathrm{AB}$ & $\mathrm{BB}$ & $\mathrm{A}$ & $\mathrm{B}$ \\
\hline Ngantang & 5 & $0(0.00)$ & $1(0.20)$ & $4(0.80)$ & 0.1 & 0.9 \\
Boyolali & 5 & $0(0.00)$ & $1(0.20)$ & $4(0.80)$ & 0.1 & 0.9 \\
BET & 5 & $0(0.00)$ & $2(0.40)$ & $3(0.60)$ & 0.2 & 0.8 \\
KPSBU & 5 & $0(0.00)$ & $2(0.40)$ & $3(0.60)$ & 0.2 & 0.8 \\
BPPT & 5 & $0(0.00)$ & $3(0.60)$ & $2(0.40)$ & 0.3 & 0.7 \\
Bali & 5 & $0(0.00)$ & $3(0.60)$ & $2(0.40)$ & 0.3 & 0.7 \\
Kunak & 5 & $1(0.20)$ & $1(0.20)$ & $3(0.60)$ & 0.3 & 0.7 \\
Singosari & 5 & $0(0.00)$ & $4(0.80)$ & $1(0.20)$ & 0.4 & 0.6 \\
Pasir Kemis & 5 & $0(0.00)$ & $3(0.60)$ & $2(0.40)$ & 0.3 & 0.7 \\
Sum & 45 & $1(0.02)$ & $20(0.44)$ & $24(0.53)$ & 0.25 & 0.75 \\
\hline
\end{tabular}

801 individuals belonging to nine native Bp breeds. PCR product of Pitl gene were digested with Alul restriction enzyme. There were three genotypes, CC, TC and TT. Lan et al. (2007) reported relationships between AluI PCR-RFLPs and eight production traits of 663 samples were done. Significant association of different genotypes with milk yield $(\mathrm{P} \varangle 0.05)$ and birth weight $(\mathrm{P} \varangle 0.05)$ implied that Pit1 gene had positive effect on milk performance and early weight. While goat Pit1 gene did not significant effect on her traits.

Genetic variability (Tables 2 and 3) results in both cattle breeds for the two studied genes indicated the low variation. The high prevalence of $\mathrm{B}$ allele and $\mathrm{BB}$ genotype suggested almost near fixation of $B$ allele in Indonesian buffaloes. That may be indicated the specific allele in Indonesian buffaloes.

\section{CONCLUSION}

No polymorphism found in Pit1|Hinf1 locus in Indonesian buffaloes. The overall genotype frequencies for Pit1 gene was BB (100\%). Therefore, Pit1|Hinf1 locus could not be used as a marker for meat production. There was high variation of Pit1 gene in Friesian Holstein cows with genotype frequencies of $\mathrm{AA}, \mathrm{AB}$, and $\mathrm{BB}$ were $0.02,0.44$, and 0.53 respectively. Gene frequencies of A allele and B allele in Pit1 were 0.25 and 0.75, respectively. Association between Pit1|Hinf1 locus variation with milk production for Friesian Holstein cows could be further investigated.

\section{REFERENCES}

Castrillo, J. L., L. E. Theill, \& M. Karin. 1991. Function of the homeodomain protein GHF1 in pituitary cell proliferation. Science 253: 197-199

Curi, R. A., D. A. Palmieri, L. Suguisawa, H. N. Olievera, A. C. Silviera, \& C. R. Lopes. 2006. Growth and carcass traits associated with GH|Alu1 I and POU1F1|Hinf 1 gene polymorphism in Zebu and crossbred beef cattle. Genet. Mol. Bio. 29 56-61

Dybus, A., I Szatkowska., E. C. Czerniawska-Piatkowska., W. Grzesiak., J. Wojcik., E. Rzewucka, \& S. Zych. 2004. Pit1Hinf1 gene polymorphism and its associations with milk production traits in Polish Black-and-White cattle. Archiv fur Tierzchut 4: 557-563

FAO \& IIEF. 2000. World Watch List for Domestic Animal Diversity. 3rd ed. Information Division, FAO, Rome.

Javanmard, A., N. Asadazadeh, H. M. Banabazi, \& J. Tavakolian. 2005. The allele and genotype frequencies of bovine pituitaryspecific transcription factor and leptin genes in Iranian cattle and buffalo populations using PCR-RFLP. Irianian J. Biotechnol. 3: 104-108.

Jawasreh, K. I. Z., F. Awawdeh, I. Rawashdeh, F. Hejazeen, \& M. Al-Talib. 2009. The allele and genotype frequencies of bovine pituitary specific transcription factor and leptin genes in Jordanian cattle population by using PCR-RFLP. Aust. J. Basic Appl. Sci. 3:1601-1606.

Kierstein, G., M. Vallinoto, A. Silva, M. P. Scheineider, L. Iannusi, \& B. Brenig. 2004. Analysis of mitochondrial D loop region cats new light on domestic water buffalo (Bubalus bubalis Phylogeny). Mol. Phyl. Evo. 30: 308-324.

Kishimoto, M, Y. Okimura, K. Yagita, G. Iguchi, M. Fumoto, K. Iida, H. Kaji, H. Okamura, \& K. Chihara. 2002. Novel 
function of the transactivation domain of a pituitaryspecific transcription factor, Pit-1. J. Biol. Chem. 277: 45141-45148.

Lan, X. Y., C. Y. Pan, H. Chen, C. L. Zhang, J. Y. Li, M. Zhao., C. Z. Lei, A. L. Zhang, \& L. Zhang. 2007. An AluI PCRRFLP detecting a silent allele at the goat POU1F1 locus and its association with production traits. Small Rum. Res. 73:8-12.

Lan, X. Y., C. Y. Pana, J. Y. Li, Y. W. Guoa, S. Hua, J. Wanga, Y. B. Liu, S. R. Hua, C. Z. Lei, \& H. Chena. 2009. Twelve novel SNPs of the goat POU1F1 gene and their associations with cashmere traits. Small Rum. Res. 85: 116-121.

Moody, D. E., D. Pomp, \& W. Berndes. 1995. Restriction fragment length polymorphism in amplification products of bovine Pit1 gene and assignment of Pit1 to bovine chromosome 1. Anim Gene 26:45-47.

Nei, M. K. S. 2000. Molecular Evolution and Phylogenetics. Oxford University Press, New York.

Renaville, R., N. Gengleer, E. Vrech, A. Prandi, S. Massart, C. Corradini, C. Bertozzi, F. Mortiax, A. Burny, \& D. Portetelle. 1997. Pit-1 gene polymorphism, milk and conformation traits for Italian Holstein-Friesian Bulls. J. Dairy Sci. 80: 3431-3438

Sambrook, J., E. F. Fritsch, \& T. Maniatis. 1989. Molecular Cloning: a Laboratory Manual. United State of America: CSH Laboratory Press.

Sumantri, C., D. Herdiana, A. Farajallah, \& D. Rahmat. 2009. Keragaman gen pituitary spesific transcription factor 1 lokus Pit1 hinf1 dan pengaruhnya terhadap bobot induk dan produksi susu pada domba lokal. JITV.14:222-229
Wollard, J., C. K. Tuggle, \& F. A. Ponce de leon. 2000. Rapid communication : Localization of POU1F1 to bovine, ovine, and caprine Iq21-22. J. Anim. Sci 78: 242-242.

Woollard, J., C. B. Schmitz, A. E. Freeman, \& C. K. Tuggle. 1994. Rapid communication: HinfI polymorphism at the bovine Pit1 locus. J. Anim. Sci. 72: 3267

Xue, K., H. Chen, S. Wang, X. Cai, B. Liu, C-F Zhang, C-Z Lei, X-Z Wang, Y-M Wang, \& H. Niu. 2006. Effect of genetic variations of the POU1F1 gene on growth traits of Nanyang cattle. Acta Genetica Sinica. 33:901-907.

Yu, T. P., C. K. Tuggle, C. B. Schmitz, \& M. F. Rothschild. 1995. Association of PIT1 polymorphisms with growth and carcass traits in pigs. J. Anim. Sci. 73:1282-1288

Zwierzchowski, L., J. Krzyzewski, N. Strzalkowska, E. Siadkowska, \& Z. Ryniewicz. 2002. Effects of polymorphism of growth hormone (GH), Pit-1, and leptin (LEP) genes, cow's age, lactation stage and somatic cell count on milk yield and composition of Polish Black and White cows. Anim. Sci. Pap. Rep, 20: 213-227.

Zwierzchowski, L., J. Oprzadek, E. Dymnicki, \& P. Dzierzbicki. 2001. An association of growth hormone, kappa- casein, beta-lactoglobulin, leptin and Pit-1 loci poly- morphism with growth rate and carcass traits in beef cattle. Anim. Sci. Pap. Rep. 19: 65-77.

Zhao, Q. 2002. Genetic markers for genes encoding Pit-1, GHRH-receptor, and IGF-II, and their association with growth and carcass traits in beef cattle. Dissertation. Department of Animal Science. The Ohio State University. 